\title{
Felles europeisk profesjonskort og varsling av autorisasjonstap
}

\author{
EUs kvalifikasjonsdirektiv er revidert. I direktivet er det gjort endringer som vil få betydning for norske leger.
}

Kvalifikasjonsdirektivet legger til rette for gjensidig godkjenning/konvertering av kvalifikasjonsbevis, autorisasjoner og spesialistgodkjenninger EU-landene imellom. Direktivet gjelder ikke bare helsepersonell, men en rekke profesjonsgrupper. Direktiver er rettslig bindende, og alle medlemsstater, inkludert EØS-landene, er pålagt å innføre disse gjennom egen lovgivning.

Legeforeningen har fulgt arbeidet med nytt kvalifikasjonsdirektiv gjennom deltakelsen i den europeiske legeforeningen (CPME).

Et revidert direktiv ble vedtatt i november 2013. Dette viderefører stort sett tidligere reguleringer, men inneholder enkelte nye bestemmelser som også vil få betydning for leger i Norge. Blant endringene er nye regler om en europeisk varslingsordning for tilsynsreaksjoner og innføring av et såkalt elektronisk profesjonskort. Det pågår et aktivt arbeid i EU-kommisjonen i Brussel for å finne hensiktsmessige løsninger for disse nyordningene. Den europeiske legeforeningen er involvert i dette arbeidet.

\section{Elektronisk europeisk «profesjonskort»}

Det har vært mye debatt rundt innføringen av et såkalt europeisk profesjonskort. Formålet med dette kortet skulle være å legitimere at innehaveren oppfylte bestemte kvalifikasjonskrav og dermed gjøre det unødvendig med annen dokumentasjon dersom man skulle ta jobb i et annet EU-land.

Lenge var planen en obligatorisk ordning med et fysisk plastkort. Forslaget møtte en del motstand. Flere medlemsland mente at kravene til dokumentasjon og godkjenning var så ulike landene imellom at det for flere profesjoner ikke ville være noen god løsning med en slik standardisert ordning. Videre ble det uttalt at det allerede finnes løsninger for dette i flere land - på ulike tekniske plattformer - og at det ville være uhensiktsmessig å stille krav om én bestemt teknisk løsning.

Den europeiske legeforeningen har etter innspill fra medlemsorganisasjonene støttet innføring av en frivillig ordning for et standardisert elektronisk system for dokumentasjon av kvalifikasjoner. Ideen om et fysisk kort er med andre ord forlatt. Dette vil etter alt å dømme bli innført som en ny elektro- nisk modul i et system for informasjonsutveksling mellom medlemslandene, det såkalte Internal Market Information system (IMI).

I dag lagrer ikke IMI-systemet informasjon om kvalifikasjonene til (helse)personell. Om man i ett land lurer på om en lege har de nødvendige yrkeskvalifikasjoner fra et annet land, kan det allerede i dag gjøres en forespørsel gjennom IMI-systemet. Da vil spørsmålet gå videre til aktuell myndig-

\section{«For Legeforeningen har det vært viktig at ordningen er strengt begrenset til rettighetstap»}

het i landet der søkeren har tatt sin utdanning, som så må formidle dokumentasjonen tilbake gjennom systemet. I et nytt system vil legen kunne velge å legge inn kvalifikasjonsbevisene i IMI og dermed slippe dokumentasjonsarbeidet $\mathrm{i}$ forbindelse med jobbing $\mathrm{i}$ andre europeiske land.

\section{Når innføres ordningen?}

Ordningen vil bli gradvis innført for ulike profesjoner. Når dette blir aktuelt for legene er usikkert, men kommisjonen har allerede signalisert et ønske om tidlig innfasing, da dette er en yrkesgruppe med høy mobilitet. Samtidig har kommisjonen gitt uttrykk for at pilotering ikke er aktuelt og at gjennomføringen skal skje fullskala for hver yrkesgruppe.

Blant annet den britiske og den nederlandske legeforeningen har flagget motstand, fordi de mener standardiseringen vil by på pasientsikkerhetsutfordringer. Etter deres oppfatning vil man miste tilstrekkelig oversikt over hva som ligger bak godkjenningen og ha for liten adgang til å be om ytterligere dokumentasjon - dette fordi det bare er ved begrunnet mistanke om feil at ytterligere dokumentasjon skal kunne utbes.

Det blir også påpekt at det er viktig med tid til å påse at de ulike lands godkjenningsmyndigheter (i Norge SAK) har tilstrekkelige systemer på plass til å sørge for at den nye ordningen kan tas i bruk med høy grad av tillit.

Saken ble drøftet i CPMEs møte i Brussel $\mathrm{i}$ begynnelsen av april $\mathrm{i}$ år. Her ble det bestemt at CPME skal motarbeide at ordningen innføres for leger som første yrkesgruppe på bakgrunn av ovennevnte innvendinger. Den norske legeforening støtter denne vurderingen.

\section{Varslingsordning for autorisasjonstap}

Direktivet stiller også krav til innføring av en europeisk varslingsordning for autorisasjonstap. I dag gjelder en slik ordning mellom de nordiske landene, basert på en egen avtale. Direktivet stiller krav om at en slik ordning skal være på plass for hele Europa i løpet av to år.

For Legeforeningen har det vært viktig at ordningen er strengt begrenset til rettighetstap. Det er ulike systemer for tilsynsreaksjoner i de ulike land, og Norge er blant de landene hvor tilsynsmyndighetene har størst myndighet til å vedta formelle reaksjoner. Om alle tilsynsreaksjoner, for eksempel også advarsler, skulle meldes, ville dette være uforholdsmessig inngripende for norske leger.

Våre synspunkter på dette har fått gehør gjennom den europeiske legeforeningens arbeid. Det vil kun være i de tilfeller hvor man har mistet retten eller fătt begrenset retten til å praktisere samt tilfeller hvor man er tatt for forfalskning av kvalifikasjonspapirer at varsling skal skje etter dette systemet.

\section{Lars Duvaland}

lars.duvaland@legeforeningen.no

Lars Duvaland (f. 1974) er advokat og assisterende direktør i Avdeling for jus og arbeidsliv, Den norske legeforening. Ingen oppgitte interessekonflikter. 